\title{
Goat Breeding Objectives in Relation To Agroecological Zonation Under Dryland Farming Conditions of North Kordofan, Sudan
}

Faisal M El Hagi3*, Mitsuru Tsubo', Mourad Rekik², Aynalem Haile², Tesfaye Getachew ${ }^{2}$, M Hilali², Abdelrahman A Khatir ${ }^{3}$, Imad Eldin A Ali Babiker ${ }^{3}$, Abuelgasim I Musa', Mohamed-Khair A Ahmed ${ }^{4}$, Mahgoub G El Hag ${ }^{4}$ and Sumaya A Zakieldeen ${ }^{5}$

${ }^{1}$ Arid Land Research Center (ALRC), Tottori University, Tottori 680-0001, Japan

${ }^{2}$ International Center for Agricultural Research in Dry Areas (ICARDA), Jordon

${ }^{3}$ Agricultural Research Corporation (ARC), Sudan

${ }^{4}$ Faculty of Animal Production, University of Khartoum, Khartoum, Sudan

Institute of Environmental Studies, University of Khartoum, Sudan

*Corresponding author: Faisal M El Hag, Arid Land Research Center (ALRC),

Tottori University, 1390 Hamasaka, Tottori 680-0001, Japan.
Received Date: May 14, 2020

Published Date: May 29, 2020

\begin{abstract}
Twelve focus group discussions and 164 individual farmer interviews were held in 12 villages under dryland farming in different agroecological zones in North Kordofan, Sudan, during November-December 2018. The aim was to describe goat breeding objectives, ownership, and population distribution in relation to agroecological zones. Data and information collected were analyzed for descriptive statistics using SPSS (ver. 24). The highest goat numbers were in the semidesert (41.9\%) and arid (35.0\%) zones, holding over $75 \%$ of goat population. Overall percentage of households owning goats was $70.9 \%$, with average flock size of four heads, mostly (94.9\%) owned by women. Mature does constituted over $70.0 \%$ and female yearlings about $21.9 \%$. No controlled mating over goat flocks was practiced, with an average of 77 goats per breeding buck. Kidding occurs mainly during the rainy and winter seasons. Lactating does were mostly (99.5\%) milked once a day every morning. Milk production was ranked as the most important reason for raising goats across all agroecological zones, with highest indices at the semiarid on sand (index 0.886) and semiarid on clay (index 0.723) zones, followed by the semidesert zone (Index 0.633), and lowest indices (Index 0.500) at the desert and arid zones. Meat production was ranked 2nd in the desert (index 0.270 ) and semiarid on clay (index 0.262 ) zones, while income generation was ranked second across semidesert (index 0.300), semiarid on sand (index 0.345) and arid (0.068) zones. It was concluded that goat breeding objectives in the region should focus on milk production. Nonetheless, the multipurpose nature of goats (milk, meat, income generation, etc.) under low-input traditional dryland production systems should be taken into considerations when attempting improvement programs. Furthermore, there is a high need for genomic/genetic characterization of different goat subtypes/breeds in North Kordofan and Sudan at large.
\end{abstract}

Keywords: Goats; Breeding objectives; Agroecological zones; Dryland; Rank index

\section{Introduction}

Goats are one of the most important livestock species in rural farming systems in Sudan and the most widely distributed animal in the country. They occupy the second position after sheep in population size and third position in economic importance after cattle and sheep [1]. Increasing pressure on land and natural resources, poverty, hunger, changing climatic conditions, and pricing of livestock products driven by increased population and consumer demand present unprecedented development challenges for smallholder traditional dryland farming communities [2]. Improvement of livestock production using more productive livestock genotypes has been advocated as a sustainable means of improving the livelihoods of some of the poorest farmers [3]. 
In Sudan, the productivity and contribution of goats to the national economy is relatively low. The value of livestock exports declined from US \$908.6 million in 2015 to US \$ 762.9 million in 2016 by $16.0 \%$, as a result of decline in the value of goat and sheep exports by $39.5 \%$ and $26.2 \%$ respectively [4]. This may be due to different factors such as climate change as reflected in poor nutrition and high prevalence of diseases, coupled with lack of appropriate breed and breeding strategies.

Official efforts to improve milk production in Sudanese goats have started since 1976 through importing a number of exotic breeds [5]. Temperate goat breeds (Saanen, Tugenburger, AngloNubian and Alpine) are frequently owned by individuals and/or in hands of few goat keepers in the country. Damascus goats and bucks have also been introduced recently by IFAD-WSRMP in Kordofan in 2009 [6]. This study was undertaken with the aim of describing ownership and flock structures under different agroecological zones of the dryland farming conditions in North Kordofan region, Sudan and of defining breeding objectives of goats under dryland smallholder farming conditions.

\section{Materials and Methods}

\section{Study area}

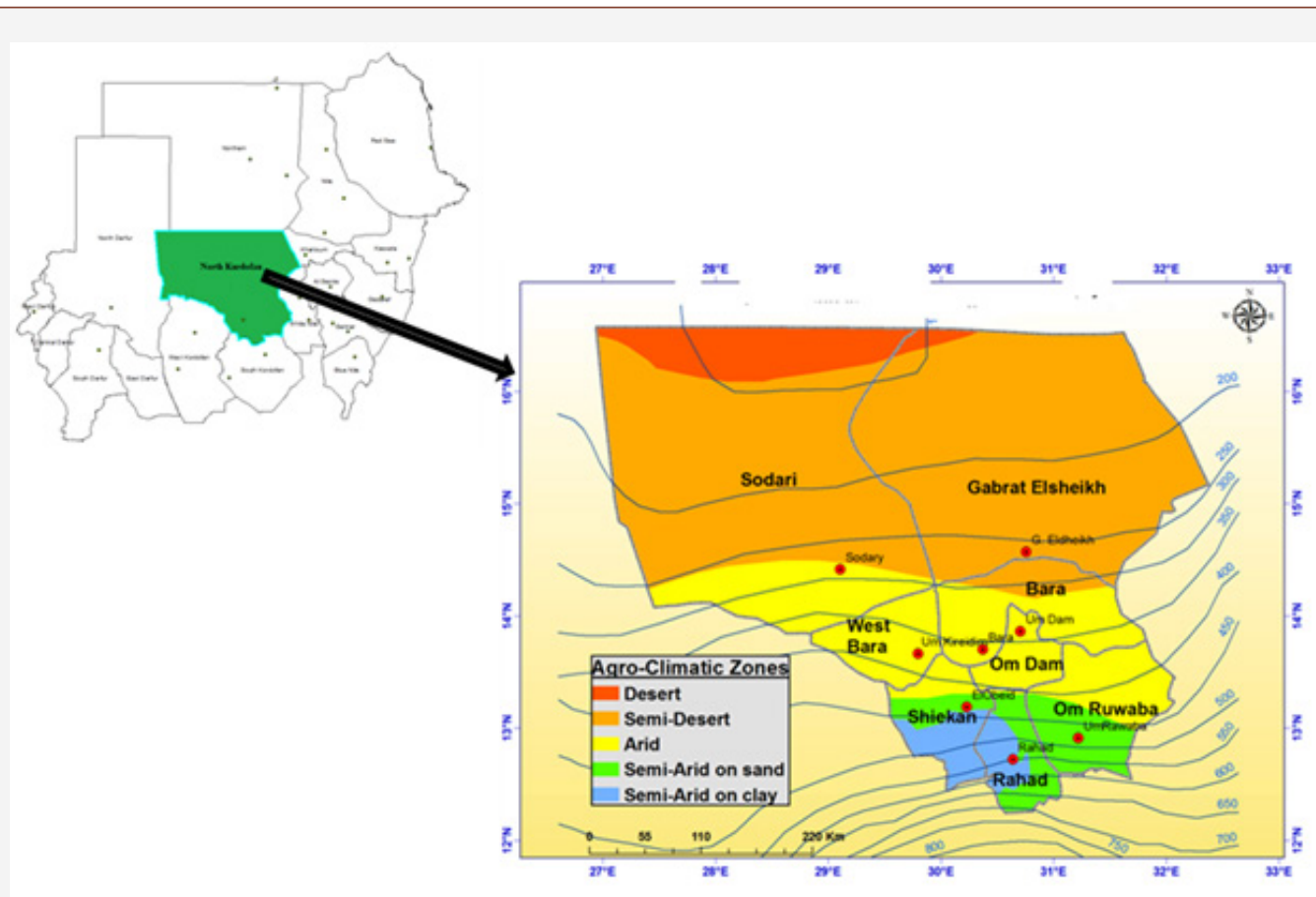

Plate 1: Agroecological zones, isohyets and localities of North Kordofan, Sudan.

Northern Kordofan lies is in the central western part of Sudan on the northern edge of the Savannah belt (lat. $11-17^{\circ} \mathrm{N}$; longit. 27-32 ${ }^{\circ} \mathrm{E}$ ), with an area of $242,000 \mathrm{~km}^{2}$ [7]. The human population is estimated at 2.921 million, accounting for $9.2 \%$ of Sudan total population, with a male to female ratio of 0.93 [8]. The climate is characterized by low rainfall, sparse vegetation and extreme temperatures, reaching as high as $49{ }^{\circ} \mathrm{C}$ in summer (March-Sept) and as low as $15.0{ }^{\circ} \mathrm{C}$ in winter (Oct-Feb) [7]. The region was divided into four agroecological zones (AEZs) (Figure 1); desert, semidesert, semiarid and arid [9]. The desert zone covers a very small area (5\%), the semidesert $48 \%$, arid zone $25 \%$ and semiarid zone $22 \%$. The semiarid zone is further subdivided into semiarid on sand and semiarid on clay. Soils in the area include sandy soils (more than 60\%), clay soils (6\%), Clay-loamy soils (18\%), and other important soils include loamy soils locally known as "Gardud" soils (2\%) [10]. The important land use categories are rangelands comprising about $50.6 \%$ of the region area, traditional rainfed agriculture $22.1 \%$, forest area occupying $1.82 \%$, and bare areas $25.2 \%$ (Table 1). 
Table 1: Various land use categories and their areas ('000 ha) in North Kordofan.

\begin{tabular}{|c|c|c|}
\hline Land Use & Area & As \% of North Kordofan \\
\hline Post flooding Agriculture & 4.2 & 0.03 \\
\hline Mechanized Agriculture. & 3.5 & 0.02 \\
\hline Rain-fed Agriculture & $5,379.90$ & 22.1 \\
\hline Rangeland & $12,271.80$ & 50.6 \\
\hline Forests & 437.5 & 1.82 \\
\hline Water bodies & 47.6 & 0.23 \\
\hline Bare area & $6,121.70$ & 25.2 \\
\hline Total & 24266.2 & 100 \\
\hline
\end{tabular}

\section{Data collection}

Information used for this study included both primary and secondary data. Sources of secondary data were Federal and Kordofan Ministries of Agriculture and Animal Resources, the International Fund for Agricultural Development - Western Sudan Natural Resources Management Program (IFAD-WSRMP), Annual research reports of El-Obeid Research Station (Sudanese Agricultural Research Corporation) and others. Other secondary data sources were published and unpublished reports, scientific articles and documents covering livestock in general and goats in North Kordofan in particular. These documents and others were thoroughly reviewed for goat distribution in relation to agroecological zones.

Assigning goat population to agroecological zones: Goat data are usually recorded at administration level, hence there is no data available at agroecological zone level. The later would be more important for breeding and management decision as these are more associated with agroecology than the administrative divisions. The method described by Toxopeus [11] was adopted to classify population by agroecology. Area of each locality in a certain AEZ was calculated as percentage of the total area of that AEZ "Aerial factor". To calculate the total goat population in each AEZ, the goat statistics in each locality in that AEZ was multiplied by its "aerial factor" (Table 2).

Table 2: Localities aerial factors* in each agroecological zone.

\begin{tabular}{|c|c|c|c|c|c|}
\hline Locality /AEZ & Desert & Semi-Desert & Arid & Semi-Arid on Clay & Semi-Arid on Sand \\
\hline Sodari & 0.1584 & 0.6833 & 0.1584 & 0 & 0 \\
\hline Gabrat el Sheikh & 0.0165 & 0.9829 & 0.0006 & 0 & 0 \\
\hline Bara & 0 & 0.255 & 0.7448 & 0 & 0 \\
\hline Um Ruwaba & 0 & 0 & 0.5575 & 0 & 0 \\
\hline Um Daam & 0 & 0 & 1.0007 & 0.4429 \\
\hline Er Rahad & 0 & 0 & 0.0249 & 0.5605 \\
\hline West Bara & 0 & 0 & 0.9994 & 0 & 0.2761 \\
\hline Sheikan & 0 & 0 & 0.2565 & 0.468 & 0.2761 \\
\hline
\end{tabular}

${ }^{*}$ calculated according to Toxopeus (1999). AEZ = Agroecological zone

Primary data: Primary data were collected from various localities and villages in different agroecological zones in North Kordofan (Figure 1), using various methods during NovemberDecember 2018. These included direct field observations of goat numbers within each agroecological zone, flock husbandry and structures as perceived by farmers (both men and women). Rapid Rural Appraisal (RRA) was performed through a checklist using focus group discussions with goat owners (men and women) in randomly chosen villages in different agroecological zones. Elements of discussion included the total number of households owning goats, size of goat holdings per household, goat flock structure, wet and dry season feed resources, flock breeding season and management (buck: doe ratio, controlled breeding,). Interviews with key informants was an integral activity of focus group discussion. Key informants included individuals involved in the service sector of livestock, agriculture, producer groups, executive authorities and local leaders.
A short personal interview was conducted to gain insight on the reasons for raising goats at the four agroecological zones in North Kordofan. Fourteen (14) farmers were interviewed at the desert zone, 50 at the semidesert zone, 40 at the arid zone, 40 at the semiarid on sand zone and 20 at the semiarid on clay zone. Farmers were asked individually to provide their reasons for raising goats and to rank them as $1^{\text {st }}, 2^{\text {nd }}$, and $3^{\text {rd }}$ priority.

\section{Data arrangement and analysis}

Data and information collected through focus group discussions were categorized and coded whenever necessary and analyzed for descriptive statistics using SPSS (ver. 24) software program. Indices were calculated for all ranking data according to a formula: index $=$ sum of $(3$ for number of farmers ranked first +2 for number of farmers ranked second +1 for number of farmers ranked third) given for each purpose divided by sum of ( 3 for number of farmers ranked first +2 for number of farmers ranked second +1 for 
number of farmers ranked third) for all reason of raising goats in a study agroecological zone, in accordance with Kosgey [12], to gain insight on reason for raising goats and breeding objectives.

\section{Results and Discussion}

\section{Goat population in relation to agroecological zones in North Kordofan}

Goat population in Sudan is estimated at 32.2 million heads [13], with $2.5 \%$ annual growth rate. Goat population in North Kordofan (2.7 million heads) represented $37.1 \%$ of the total goat population in the Western Region (Greater Kordofan and Greater Darfur; 7.2 million goats) and $8.5 \%$ of Sudan (Table 3). Within North Kordofan, goats accounted for $31.3 \%$ of the livestock population, which is second to sheep. However, sources differ widely in estimates of livestock numbers in Sudan and actual figures can be disputed [1].
The only livestock census was in 1975-77 [14] and annual figures are based on growth rates which might over- or under-estimate actual numbers in view of the many changes that have occurred in the region (droughts, insecurity, mass migrations, export, changes in production system) [1].

The highest goat population in North Kordofan (Table 4) was found in the semidesert (41.9\%), followed by the arid zone (35.0\%). These two agroecological zones had over $75 \%$ of goat population in North Kordofan, with the least numbers in the desert (4.6\%) and semiarid on clay $(6.3 \%)$ zones. The region has been drastically affected by frequent drought spells [15] during the course of 1974, $1984 / 85,1990,1991,2004,2001$, and 2011, and that the drought episode of 1984/85 has wiped out most of the small ruminants from the region, particularly at the desert zone in the far northern part [6].

Table 3: Livestock population by class of animal in North Kordofan in relation to Western Sudan and Sudan.

\begin{tabular}{|c|c|c|c|c|c|}
\hline & Camels & Goats & Sheep & Cattle & \\
\hline Population Size: & & & & \\
\hline North Kordofan & 923,328 & $2,654,295$ & $4,141,630$ & 759,400 & $8,478,653$ \\
\hline Sudan & $4,809,000$ & $31,227,957$ & $40,208,546$ & 30376002 & $106,621,505$ \\
\hline Western region & $1,801,451$ & $7,150,983$ & $10,595,335$ & $8,605,521$ & $28,153,290$ \\
\hline As Percent of: & & & & & \\
\hline Sudan & 19.2 & 8.5 & 10.3 & 2.5 & 8.9 \\
\hline Western Region & 51.3 & 37.1 & 39.1 & 8.8 & 30.1 \\
\hline North Kordofan livestock population & 10.9 & 31.3 & 48.8 & 8.9 & \\
\hline
\end{tabular}

Source: computed from the records of MARF (2016).

Table 4: Total numbers of goats (heads) in each agroecological zone (AEZ) of North Kordofan (NK).

\begin{tabular}{|c|c|c|c|c|c|c|}
\hline Locality / AEZ & Desert & Semi-Desert & Arid & Semi-Arid/Clay & Semi-Arid/Sand & Total \\
\hline Sodari & 111,520 & 480,992 & 111,486 & - & - & 703,998 \\
\hline Gabrat el Sheikh & 9,982 & 595,709 & 385 & - & - & 606,076 \\
\hline Bara & - & 35,236 & 102,896 & - & 217,796 & 491,949 \\
\hline Um Ruwaba & - & - & 274,153 & - & - & 193,083 \\
\hline Um Daam & - & - & 193,083 & - & 13,227 & 23,635 \\
\hline Er Rahad & - & - & 588 & 9,820 & - & 161,456 \\
\hline West Bara & - & - & 161,456 & - & 92,839 & 336,486 \\
\hline Sheikan & - & - & 86,263 & 157,384 & 323,799 & $2,654,295$ \\
\hline Total goats & 121,479 & $1,111,719$ & 930,128 & 167,170 & 12.2 & \\
\hline
\end{tabular}

Size of goat holdings, flock structure and main husbandry practices

Total number of households (HHs) in the twelve surveyed villages was 1,478 $\mathrm{HHs}$, with a range of 65-140 $\mathrm{HHs}$ per village (Table 5). Overall percentage of HHs owning goats within these village was $70.9 \%$. Overall size of goat holdings was 4 heads per $\mathrm{HH}$, with a range of 2-6 goats/HH. Higher flock sizes of 9.9 and 12.5 goats/HH were reported by Sheriff et al. [16] for Oromo and Arab goat keepers in north-western Ethiopia, respectively. The majority of HH's goat flock was found to be composed of over 70.0\% mature does whereas yearling females accounted for $21.9 \%$ of the flock (Table 5). The proportion of female animals in small ruminant flocks in Sub Saharan Africa is usually within the range of 67-75\% [2]. Mohamed Ali \& Eldaw [17], studying Sudanese Desert goats in North Kordofan, Sudan, noticed that flocks were mainly (86.38\%) composed of females with different ages. The majority (95.0\%) of goat flocks within these villages are owned by women who are responsible for their rearing, milking and different management aspects. 
Table 5: Size of goat holdings*, goats/buck, and some management practices as reported in focus group discussions (FGDs) at villages across different agroecological zones in North Kordofan region, Sudan.

\begin{tabular}{|c|c|c|c|c|c|c|}
\hline \multirow[b]{2}{*}{ Parameter } & \multicolumn{5}{|c|}{ Agroecological Zone (AEZ) } & \multirow[b]{2}{*}{ Total Averages } \\
\hline & Desert & $\begin{array}{l}\text { Semides- } \\
\text { ert }\end{array}$ & Arid & $\begin{array}{c}\text { Semiarid on } \\
\text { Sand }\end{array}$ & $\begin{array}{c}\text { Semiarid on } \\
\text { Clay }\end{array}$ & \\
\hline Total No. of villages surveyed & 2 & 3 & 3 & 2 & 2 & 12 \\
\hline Total No. of HHs & 110 & 380 & 348 & 280 & 360 & 1478 \\
\hline Average No. of HHs per village & 65 & 127 & 116 & 140 & 120 & 123 \\
\hline Total No. of HHs owning goats & 60 & 283 & 255 & 195 & 250 & 1043 \\
\hline No. persons attending FGDs & 45 & 120 & 85 & 107 & 77 & 434 \\
\hline No. of women owning goats & 43 & 110 & 82 & 102 & 75 & $412(94.9)$ \\
\hline No. of men owning goats & 2 & 10 & 3 & 5 & 2 & $22(5.1)$ \\
\hline No. of HHs owning goats as $\%$ of total HHs & 54.5 & 74.5 & 73.3 & 69.6 & 69.4 & 70.9 \\
\hline Range of HHs per village & $50-60$ & $70-120$ & $80-120$ & $70-280$ & $90-150$ & $50-280$ \\
\hline Total No. of goats in all villages surveyed & 350 & 2200 & 1950 & 1150 & 750 & 6400 \\
\hline Average No. of Goats per HH & 3 & 6 & 6 & 4 & 2 & 4 \\
\hline \multicolumn{7}{|l|}{ Average goat flock structure: } \\
\hline Total no. of female goats & 350 & 2200 & 1950 & 1150 & 750 & \\
\hline$\S$ Does 3-4 years old & $25(7.1)$ & $230(10.5)$ & $120(6.2)$ & $110(9.6)$ & $35(4.7)$ & $520(8.1)$ \\
\hline$\S$ Does $1-2.5$ years old & $\begin{array}{c}240 \\
(68.6) \\
\end{array}$ & $\begin{array}{l}1460 \\
(66.4)\end{array}$ & $\begin{array}{l}1450 \\
(74.4)\end{array}$ & $780(67.8)$ & $550(73.3)$ & $4480(70.0)$ \\
\hline$\S$ Yearlings female goats & $85(24.3)$ & $510(23.2)$ & $380(19.5)$ & $260(22.6)$ & $165(22.0)$ & $1400(21.9)$ \\
\hline No. of breeding bucks & 7 & 14 & 12 & 10 & 9 & 52 \\
\hline Average number of goats per buck & 34 & 104 & 120 & 78 & 61 & 77 \\
\hline \multicolumn{7}{|l|}{ Goat milking: } \\
\hline$\S$ Once a day & 60 & 280 & 253 & 195 & 250 & $1038(99.5)$ \\
\hline$\S$ Twice a day & 0 & 3 & 2 & 0 & 0 & $5(0.50)$ \\
\hline Breeding season & \multicolumn{6}{|c|}{ All year round } \\
\hline Kidding season & \multicolumn{6}{|c|}{ Rainy (July-Oct) and Winter (November- February) } \\
\hline Feed resources & \multicolumn{6}{|c|}{ Natural Rangelands and crop residues } \\
\hline
\end{tabular}

${ }^{*}$ Numbers between parenthesis are percentages, $\mathrm{HH}=$ Household, No. $=$ Number

All respondents in group discussions within these villages across all agroecological zones stated that they impose no mating control over their goat flocks, with only few breeding bucks present at the village. Number of does per buck ranged from 34-120, giving an average number of 77 does per breeding buck. Sisay et al., [18] in Shinile and Jijiga in Ethiopia reported a lower buck: doe ratio of 1:30-50. Villagers reported that they usually do not retain male kids and were either sold or slaughtered immediately after weaning at three months of age. This is in line with Asefa et al. [19] who studying breeding objectives, selection criteria and breeding system of indigenous goat types in Bale zone, Oromia, Ethiopia, indicated that male goats were culled or sold at young age most probably before weaning. This could probably be attributed to that farmers tend to allow only few breeding bucks within a village, based on visual appearance [19] or known records of performance of their dams. Despite no control over mating in village goat flocks, famers stated that most kidding occur in the rainy and winter seasons (Table 5). This could be justified by the fact that the majority of farmers stated that their goats depend mainly on natural grazing and browsing. Natural rangeland vegetation had their highest nutrient contents during the rainy season [20] and crop residues are accessible to grazing after crop harvest. Higher nutritious grazing resources at these times could have a flushing effect on does and prepare them for mating and conception. Most farmers (99.5\%) stated that they milk their goats once a day in the morning, except for a very few individuals $(0.5 \%)$ who milk their goats twice a day (Table 5).

\section{Reasons for Raising Goats and breeding objectives in relation to agroecological zone}

The interviewed farmers ranked their reasons for raising goats as 1 st, $2 \mathrm{nd}$, and 3rd priorities, therefore, the number of answers was larger than the number of total farmers interviewed. Overall number of farmers interviewed across all agroecological zones was 164 while the number of answers was 410 (Table 6). All interviewed farmers mentioned milk production, meat production and income generation as important reasons for raising goats (Table 6). Milk 
production was ranked as the most important reason for raising goats across all agroecological zones. The highest indices recorded for milk production were at the semiarid on sand (index 0.886) and on clay (index 0.723 ) zones, followed by the semidesert zone (Index 0.633) whereas the least indices (Index 0.500) were recorded for the desert and arid zones. Tabbaa \& Al-Atiyat [21], in Jordan, found that the majority of farmers (84\%) emphasized on breeding goats for milk production. Meat production was the 2 nd important reason for raising goats as reported by the interviewed farmers in the desert (index 0.270) and semiarid on clay (index 0.262) zones, while income generation was ranked second across semidesert, semiarid on sand and arid agroecological zones, with respective indices of $0.300,0.345$ and 0.068 (Table 6). Kebede et al. [22] in the central rift valley and Awgichew \& Abegaz [4] at the lowlands of Ethiopia found that farmers rear their goats mainly for milk and meat purposes. Under arid and semiarid on clay zones in North Kordofan cattle and sheep raising dominate [13] and probably are the most important income generating activities than goats [23]. It worth noting that sedentary small ruminant production systems dominate under semidesert and semiarid on sand and semiarid on clay zones while pastoral (camel) and agropastoral (cattle) systems prevail under desert and arid zones, respectively [1,24]. These production systems might dictate the reasons for raising goats. Sheriff et al. [16] postulated that breeding programs implemented should consider the production systems in the targeted areas.

Table 6: Purpose for raising goats as reported by the interviewed farmers at the different agroecological zones in North Kordofan region ( $\mathrm{N}=410$ ).

\begin{tabular}{|c|c|c|c|c|c|c|}
\hline \multirow{2}{*}{$\begin{array}{l}\text { Agroecological } \\
\text { Zone }\end{array}$} & \multirow{2}{*}{$\begin{array}{l}\text { No. of Interviewed } \\
\text { Farmers }\end{array}$} & \multirow{2}{*}{ Rank } & \multicolumn{3}{|c|}{ Purpose for Raising Goats } & \multirow{2}{*}{ No. of Answers } \\
\hline & & & Milk Production & Meat Production & Income Generation & \\
\hline \multirow{4}{*}{ Desert } & \multirow{4}{*}{14} & $\mathrm{R} 1$ & 10 & 2 & 2 & 14 \\
\hline & & $\mathrm{R} 2$ & 2 & 7 & 3 & 12 \\
\hline & & R3 & 3 & 0 & 5 & 8 \\
\hline & & Index & 0.5 & 0.27 & 0.229 & \\
\hline \multirow{4}{*}{ Semidesert } & \multirow{4}{*}{50} & $\mathrm{R} 1$ & 50 & 0 & 0 & 50 \\
\hline & & $\mathrm{R} 2$ & 0 & 10 & 40 & 50 \\
\hline & & R3 & 40 & 0 & 10 & 50 \\
\hline & & Index & 0.633 & 0.067 & 0.3 & \\
\hline \multirow{4}{*}{ Arid } & \multirow{4}{*}{40} & $\mathrm{R} 1$ & 40 & 0 & 0 & 40 \\
\hline & & $\mathrm{R} 2$ & 5 & 20 & 40 & 65 \\
\hline & & R3 & 0 & 0 & 10 & 10 \\
\hline & & Index & 0.5 & 0.154 & 0.346 & \\
\hline \multirow{4}{*}{ Semiarid on sand } & \multirow{4}{*}{40} & $\mathrm{R} 1$ & 40 & 0 & 0 & 40 \\
\hline & & $\mathrm{R} 2$ & 0 & 4 & 4 & 8 \\
\hline & & R3 & 36 & 0 & 4 & 40 \\
\hline & & Index & 0.886 & 0.045 & 0.068 & \\
\hline \multirow{4}{*}{ Semiarid on clay } & \multirow{4}{*}{20} & R1 & 15 & 5 & 0 & 20 \\
\hline & & $\mathrm{R} 2$ & 1 & 1 & 0 & 2 \\
\hline & & R3 & 0 & 0 & 0 & 1 \\
\hline & & Index & 0.723 & 0.262 & 0 & 410 \\
\hline
\end{tabular}

Index $=$ sum of $(3 X$ number of farmers ranked first $+2 X$ number of farmers ranked second $+1 X$ number of farmers ranked third $)$ given for each purpose divided by sum of ( $3 X$ number of farmers ranked first $+2 X$ number of farmers ranked second $+1 X$ number of farmers ranked third) for all reason of raising goats in a study agroecological zone; $\mathrm{R}=\mathrm{Rank}$

\section{Conclusion}

The results clearly indicated that milk production should be the primary breeding objective in the semiarid and semidesert zones while dual purpose goats for both milk and meat should be considered for the desert and arid zones. Nonetheless, the multipurpose nature of goats (milk, meat, cash, etc.) under lowinput traditional dryland production system should be taken into considerations when attempting improvement programs. Farmers, particularly women, capacity building on goat farming and their involvement in the initial stages of planning is a prerequisite and participatory approaches [25] be adopted when intending goat improvement programs. Furthermore, there is a high need for genetic characterization of different goat subtype/breeds in North Kordofan and Sudan at large.

\section{Acknowledgment}

This study has been prepared as demanded by the International Center for Agricultural Research in Dry Areas (ICARDA) in the framework of the project "Sudan Initiative: Increased Effectiveness 
of Agropastoral Management, Watershed Management and Sustainable Intensification of Wheat-Legume Systems" ICARDA Agreement No. 200045. We are deeply indebted to farmers and livestock producers as well as actors along the livestock sector in North Kordofan for the willingness to participate and contribute to the surveys, interviews and focus group discussions.

\section{Disclosure Statement}

All benefits in any form from a commercial party related directly or indirectly to the subject of this manuscript or any of the authors must be acknowledged. For each source of funds, both the research funder and the grant number should be given.

\section{Conflict of Interest}

No conflict of interest.

\section{References}

1. Wilson RT (2018) Livestock in the Republic of the Sudan: Policies, production, problems and possibilities. Animal Husbandry, Dairy and Veterinary Science 2(3): 1-12.

2. FAO (2017) The future of food and agriculture Trends and challenges. Food and Agriculture Organization of the United Nations (FAO), Rome, Italy, pp. 180.

3. Seré C, Van De Zijpp A, Persley G, Rege JEO (2007) Dynamics of livestock production systems, drivers of changes and prospects for animal genetic resources. FAO - (Ed.), International Technical Conference on Animal Genetic Resources for Food and Agriculture-The scientific Forum on Animal Genetic Resources, Interlaken, Switzerland.

4. CBOS (2016) Central Bank of Sudan (CBOS) 56 th Annual Report, Khartoum, Sudan, pp. 244.

5. Abulazayim M (1996) Goats. Animal Resources and Animal Production in the Sudan. Khartoum University Press, University of Khartoum Casting house, pp. 36-90.

6. IFAD-WSRMP (2012) Livestock breed characterization in the Western Sudan Resource Management Program (WSRMP) area. IFAD-WSRMP, Federal Ministry of Agriculture, El-Obeid, Sudan.

7. Sudan NAP (2016) Sudan National Adaptation Plan (Sudan NAP) to climate change. HCENR (Higher Council for Environment and Natural Resources. Khartoum, Sudan, pp. 122.

8. Sudan Population Census, 2008. Analytical Report, North Kordofan Region. Sudan 5th Population Census, 2008. Central Bureau of Statistics, pp. 182.

9. FAO, IIASA (2000) Global Agro-ecological Zones. Land and Water Digital Media Series CDROM 11. Food and Agriculture Organization of the United Nations (FAO), Rome, Italy and International Institute for Applied Systems Analysis (IIASA), Luxemburg, Austria.

10. El Tahir BA, Ahmed DM, Ardo J, Gaafard AM, Salih AA (2009) Changes in soil properties following conversion of Acacia senegal plantation to other land management systems in North Kordofan State, Sudan. Journal of Arid Environments 73: 499-505.
11. Toxopeus AG (1999) An Interactive Spatial and temporal Modelling System (ISM) as a tool for ecosystem management, PhD-thesis, ITC, the Netherlands, pp. 250.

12. Kosgey IS (2004) Breeding objectives and breeding strategies for small ruminant in the tropics, (unpublished PhD thesis, Wageningen University, the Netherlands).

13. MARF (2016) Ministry of Animal Resources, Rangelands and Fisheries (MARF) Annual Report. Khartoum, Sudan.

14. Watson RM, Tippett CI, Rizk K, Jolly F, Beckett J, et al. (1977) Sudan National Livestock Census and Resource Inventory. The results of an aerial census and resources in Sudan from August 1975 to January 1977, Sudan Vet Res Admin, Ministry of Agriculture, Food and Natural Resources, Khartoum, Sudan 31: 1-34.

15. Elhag KM, Zhang W (2018) Monitoring and Assessment of Drought Focused on Its Impact on Sorghum Yield over Sudan by Using Meteorological Drought Indices for the Period 2001-2011.

16. Sheriff O, Alemayehu K, Haile A (2019) Production systems and breeding practices of Arab and Oromo goat keepers in north western Ethiopia: implications for community-based breeding programs 52: 1467-1478.

17. Mohamed Ali MA, Eldaw AS (2015) Study of flock structure and some morphological, productive and reproductive characters of Sudanese Desert goats in North Kordofan State, Sudan. Journal of Novel Applied Sciences (JNAS) 4(11): 1155-1158.

18. Sisay T, Vijchulata P, Chairatanayuth P, Swasdiphanich S (2006) Assessment of Small Ruminant Management Practices in Jijiga and Shinile Zones of Somali Regional states, Ethiopia. Kasetsart Journal of Natural Science 40: 987-999.

19. Asefa B, Kebede K, Effa K (2015) Breeding objectives, selection criteria and breeding system of indigenous goat types in Bale zone, Oromia, Ethiopia. International Journal of Agricultural Research Innovations and Technology 5(2): 7-15.

20. Abusuwar AO, Ahmed EO (2010) Seasonal variability in nutritive value of ruminant diets under open grazing system in the semi-arid rangeland of Sudan (South Darfur State). Agriculture and Biology Journal of North America 1(3): 243-249.

21. Tabbaa MJ, Al Atiyat R (2009) Breeding objectives, selection criteria and factors influencing them for goat breeds in Jordan. Small Ruminant Research 84: 8-15.

22. Kebede T, Haile A, Dadi H (2012) Smallholder goat breeding and flock management practices in the central rift valley of Ethiopia. Tropical Animal Health and Production 44: 999-1006.

23. Awgichew K, Abegaz S (2008) Breeds of sheep and goats. In: Alemu Yami and R.C. Merkel (Eds.). Sheep and goat production handbook for Ethiopia. Ethiopia n sheep and goat productivity improvement program, USAID, pp. 5-26

24. Van Breugel P, Herrero M, Van de Steeg J, Peden D (2010) Livestock Water Use and Productivity in the Nile Basin. Ecosystems 13: 205-221.

25. Duguma G, Mirkena T, Haile A, Iñiguez I, Okeyo AM, et al. (2010) Participatory approaches to investigate breeding objectives of livestock keepers. Livestock Research for Rural Development 22: 1-11. 